\title{
Perhitungan Nilai Percepatan Tanah Maksimum Berdasar Rekaman Sinyal Accelerograph di Stasiun Pengukuran UNSO Surakarta
}

\author{
Ari Sungkowo* \\ Badan Meteorologi Klimatologi dan Geofisika, Stasiun Geofisika Klas I Yogyakarta \\ Jl. Wates km 8, Dusun Jitengan Balecatur Gamping Sleman \\ DI Yogyakarta, telp (0274-6498383) \\ *Email : ari.sungko@gmail.com
}

\section{ABSTRACT}

Recordings from strong motion accelerograph are fundamental importance in earthquake engineering, forming the basis for all of characterizations of ground shaking employed for seismic design. Peak Ground Acceleration based on seismogram Strong Motion Accelerograph data has been calculated using site sensor UNSO data. The Sensor was deployed in Hidrology laboratory, Civil Engineering, Universitas Sebelas Maret Solo Central Java. The sensor type is TSA 100 produced by Metrozet USA. The accelerogram data used from the earthquake that occurred on August 03, 2017 M 5.3 SR southwest Cilacap West Java. The absolute method was used to calculated the maximum amplitude of accelerograph data recorded by the sensor from all components. The dadiSP software used to determined Peak Ground Acceleration. Peak ground acceleration N-S component 0.307 gal, E-W component 0.302 gal and U-D component 0.133 gal. This earthquake intensity in site sensor UNSO I MMI. This site sensor UNSO can be used to determine the PGA of recorded earthquake.

Keyword: PGA, Accelerograph, Seismogram, Earthquake

\section{ABSTRAK}

Rekaman-rekaman yang dihasilkan oleh strong motion accelerograph merupakan hal yang penting dalam teknik kegempaan sebagai dasar untuk karaterisasi getaran tanah yang digunakan dalam desain seismik. Telah dilakukan perhitungan nilai percepatan tanah maksimum (PGA) menggunakan data rekaman sinyal yang terekam oleh sensor Strong Motion Accelerograph di stasiun pengukuran UNSO yang terpasang di laboratorium hidrologi fakultas teknik sipil Universitas Sebelas Maret Surakarta. Sensor yang terpasang bertipe TSA 100 yang diproduksi oleh Metrozet USA. Rekaman gempa yang digunakan dalam perhitungan ini adalah rekaman gempabumi tanggal 03 Agustus 2017 dengan magitudo 5,3 SR, epicenter gempabumi di BaratDaya Cilacap Jawa Tengah. PGA dihitung dengan metode absolut yaitu menggunakan amplitudo maksimum sinyal yang terekam di sensor. Software yang digunakan untuk menghitung PGA adalah software dadiSP. Nilai PGA pada masing -masing hasil perhitungan adalah 0,307 Gal komponen N-S, 0,302 Gal komponen E-W dan 0.133 Gal komponen U-D. Intensitas gempa di stasiun pengukuran UNSO adalah I MMI. Hasil ini menunjukan sensor UNSO dapat dipergunakan untuk mengetahui nilai PGA dari suatu dari suatu gempabumi.

Katakunci: PGA, accelerograph, Seismogram, gempabumi

\section{PENDAHULUAN}

Indonesia merupakan kawasan yang mempunyai tingkat seismisitas tinggi. Hal ini dikarenakan wilayah Indonesia dilewati jalur pertemuan empat lempeng tektonik aktif, yaitu lempeng tektonik Eurasia, Indoaustralia, Pasifik dan lempeng tektonik Philipina ${ }^{[1,2]}$. Salah satu bentuk pertemuan lempeng ini adalah subduksi atau tunjaman yaitu kondisi salah satu lempeng tektonik yang menunjam ke bawah lempeng tektonik yang lainnya. Jalur subduksi ini membentang dari sepanjang pantai barat pulau Sumatera, sepanjang selatan pulau Jawa menerus hingga selatan pulau Bali, Lombok, Flores, Maluku dan Papua. Diselatan pulau Jawa jalur subduksi lempeng Indo-Australia relatif ke utara terhadap lempeng Euroasia dengan kecepatan rata-rata 7,7 cm/tahun. Sementara lempeng Pasifik bergerak relatif kebarat terhadap lempeng Euroasia dan lempeng Indo-Australia. 
Gempabumi banyak terjadi di daerah sekitar tumbukan lempeng tektonik yang menyebabkan daerah di sekitar tumbukan lempeng ini mempunyai tingkat seismisitas yang tinggi ${ }^{[3]}$. Gempabumi dapat mengkibatkan kerusakan pada bangunan. Tingkat kerusakan bangunan akibat gempabumi tidak hanya dikontrol oleh kondisi atau kualitas bangunan saja tetapi diakibatkan oleh kondisi tanah setempat yang ditunjukan tingkat amplifikasi, respon tanah terhadap guncangan, percepatan tanah maksimum (PGA) di suatu tempat.

Estimasi percepatan tanah maksimum penting diperhitungkan untuk menetapkan desain konstruksi bangunan dan penyempurnaan tata ruang wilayah di wilayah rawan gempabumi. Utamanya pada perhitungan antara getaran tanah yang potensial menyebabkan kerusakan dan kemampuan struktur untuk menahan kerusakan.

Salah satu sensor accelerograph BMKG telah dipasang di Universitas Sebelas Maret Solo yang merupakan salah satu dari jaringan sensor accelerograph BMKG untuk mendapatkan nilai percepatan tanah dari suatu gempabumi.

Accelerograph merupakan instrumen yang digunakan untuk merekam guncangan tanah yang sangat kuat. Pada umumnya peralatan accelerograph ditempatkan di daerah untuk mengukur variasi guncangan pada struktur geologi setempat. Accelerograph sangat berguna bilamana Seismograph yang biasa digunakan untuk penentuan lokasi dan magnitude kejadian gempabumi off scale bahkan berhenti beroperasi apabila ada guncangan yang sangat kuat sehingga tidak bisa memberikan data. Accelerograph didesain mampu untuk bekerja pada saat terjadi gempabumi yang sangat kuat. Sehingga getaran tanah atau goncangan yang terjadi mampu direkam. Rekaman-rekaman accelerograph memberikan informasi nilai percepatan tanah maksimum disuatu tempat akibat adanya gempa baik lemah maupun kuat. Informasi ini dapat digunakan untuk mempelajari karakteristik getaran gempabumi serta dapat digunakan sebagai input dalam analisis rambatan gelombang, analisis dinamis bangunan, desain bangunan dan penetuan lokasi struktur tanah (geologi) yang aman. Nilai PGA dapat diperoleh melalui perhitungan metode Empiris maupun metode Absolut. Metode empiris adalah metode perhitungan nilai PGA dengan menggunakan rumus empiris sederhana, hanya menggunakan parameter jarak dan magnitudo gempa. Metode ini baik digunakan disuatu tempat tertentu tetapi tidak dapat digunakan ditempat lainnya karena beda kondisi geologi. Metode absolut adalah perhitungan nilai percepatan tanah maksimum dengan menggunakan data rekaman strong motion accelerograph. Pengukuran dilakukan dengan menghitung amplitudo maksimum komponen sinyal (zero to peak) dari rekaman accelerograph ${ }^{[4]}$. Komponen yang biasanya digunakan adalah komponen horizontal sedangkan komponen vertikal jarang digunakan karena struktur bangunan sudah didesain mampu menahan gaya axial tekan.

Berkembangnya teknologi semikonduktor memungkinkan untuk membuat suatu sistem sensor getaran yang lebih praktis dan kompak. Dengan ditemukannya sistem piezoresistive maka sensor akselerasi menjadi semakin praktis. Efek piezoresistif adalah perubahan resistivitas listrik semikonduktor atau logam saat regangan mekanis diterapkan. Piezoresistivitas adalah suatu kemampuan yang dimiliki sebagian Kristal maupun bahanbahan tertentu lainya yang dapat menghasilkan arus listrik jika mendapatkan perlakuan tekanan. Sistem kerja ini berdasarkan gaya yang bekerja pada salah satu permukaan semikonduktor. Berdasarkan hukum Newton, gaya sebanding dengan massa dikali percepatan (disebutkan dalam Prayitno dan Ponimin., 2006) ${ }^{[5]}$ dan Dadafshar, $\mathbf{M}^{[6]}$.

$$
F=m \cdot a
$$


dimana notasi $F$ adalah Gaya dalam $(N)$, m adalah massa $(\mathrm{kg})$, dan a adalah percepatan $\left(\mathrm{m} / \mathrm{s}^{2}\right)$.

Piezoelectric tranducer adalah perangkat yang menggunakan efek piezoelectric untuk mengukur tekanan, percepatan, reganagan dengan mengubahnya ke sinyal istrik. Efek piezoelectric adalah muatan yang terakumulasi pada bahan padat tertentu seperti kristal dan keramik akibat dikenai tekanan (pressure). Pada prinsipnya, efek piezoelectric diperoleh dari ketidakseimbangan distribusi arus listrik pada bahan piezoelectric yang disebabkan oleh terjadinya tegangan (stress) pada bahan tersebut dan selanjutnya mengakibatkan terjadinya regangan. Bila kedua permukaan bahan tersebut dilapisi dengan bahan logam dan lempengan kecil tembaga ditempelkan padanya, maka perubahan arus listrik ini akan mengakibatkan terjadinya sinyal tegangan listrik pada lempeng tembaga tersebut. Efek ini dapat dibalik yaitu bila tegangan listrik dikenakan pada bahan tersebut maka akan terjadi regangan. Hal ini dapat di ilustrasikan sebagai plat paralel capasitor. Muatan total yang di hasilkan oleh tranduser sebanding dengan gaya yang bekerja, yang ditunjukan oleh persamaan $2^{[5,7]}$.

$$
q=k \cdot F
$$

dimana notasi $q=$ muatan listrik (coulomb), $k=$ konstanta

Dari persamaan (1) dan (2) didapat :

$$
\frac{q}{k}=m \cdot a
$$

Nilai perubahan muatan listrik yang terjadi pada piezoelektric akan sebanding dengan nilai percepatan (q sebanding a). Oleh karena itu maka output dari piezoelektric ini sebanding dengan nilai percepatan yang kita ukur (dalam hal ini adalah percepatan permukaan tanah).

Cara kerja accelerograph adalah sebagai berikut : Getaran seismik yang merupakan besaran fisis akan ditangkap oleh sensor dalam hal ini accelerometer yang berfungsi merubah besaran fisis menjadi besaran elektik. Output dari accelerometer ini sudah berupa tegangan analog. Tegangan analog ini kemudian dirubah oleh ADC menjadi count yang sudah berbentuk nilai digital.

Tegangan digital atau tegangan puncak ke puncak $\left(V_{p p}\right)$ ini merupakan daya output dari sensor yang berfunsi sebagai inputdari digitizer. Tegangan ini kemudian dibagi dengan nilai sensitifitas alat (accelerometer) dikali resolusi untuk mendapatkan nilai Conversion Factor $(C F)$. Faktor Konversi $(\mathrm{CF})$ merupakan suatu konstanta yang dapat digunakan sebagai acuan untuk menentukan nilai dari suatu count satu amplitude gelombang gempabumi. Nilai CF ini dapat diperoleh dari spesifikasi sensor yang digunakan seperti $V_{p p}$, resolusi maupun sensitifitas. Sensitivitas accelerometer menunjukan pada tingkat berapa sensor mengubah energi mekanik menjadi sinyal listrik (output) Sensitivitas biasanya dinyatakan sebagai $\mathrm{mV} / \mathrm{g}$ (milivolt per $\mathrm{g}$ ) atau $\mathrm{pC} / \mathrm{g}$ (picocoulombs per $\mathrm{g}$ ), dimana g adalah akselerasi akibat gravitasi atau $9,81 \mathrm{~m} / \mathrm{s}^{2}$. Nilai conversion factor dapat di formulasikan sebagai berikut ${ }^{[5,8]}$ :

$$
C F=\frac{\text { Tegangan digital }\left(V_{p p}\right)}{(\text { Resolusi } \cdot \text { Senssitivitas }}=\frac{V_{p p}}{2^{n \cdot \text { sensitifitas }}}
$$

dimana Tegangan Digital $V_{p p}$ dan Sensitivitas dalam (mVolt/g) 
Nilai konversi faktor pada umumnya sudah tertentu untuk tiap-tiap komponen sensor. Nilai konversi faktor ini digunakan dalam perhitungan nila Peak Ground Acceleration (PGA) yang dirumuskan:

$$
P G A=A \max \cdot C F
$$

dimana notasi PGA adalah Percepatan tanah maksimum dalam (g), Amax adalah amplitudo maksimum (count), $C F$ adalah Conversion Factor. Jika PGA dirubah menjadi dalam gal maka rumursan diatas menjadi persamaan 7 .

$$
P G A=A \max \cdot C F \cdot 980
$$

dimana 980 adalah nilai percepatan gravitasi

\section{METODE}

\section{Data}

Data rekaman gempa yang digunakan dalam perhitungan ini adalah data rekaman gempa tanggal 3 Agustus 2017. Gempa terjadi pada pukul 23:14:23 WIB (16:14:23 UTC) dengan magnitudo 5,3 SR, kedalaman hiposenter, epicenter pada koordinat -8,36LS 108,99BT 22 $\mathrm{km}$ dilaut $73 \mathrm{~km}$ BaratDaya Cilacap Jawa Tengah. Dampak gempa ini terasa hingga daerah Sleman,Yogyakarta, Kulonprogo dengan intensitas II-III MMI serta di Bantul, Purworejo, Cilacap intensitas III MMI. Sensor accelerograph UNSO milik BMKG, yang dipasang di laboratorium teknik sipil Universitas Sebelas Maret Solo merekam getaran gempa tersebut. Rekaman 3 komponen gempa ini ditampilkan dengan software seismogram60k ditunjukan pada Gambar 1. Pada gambar 1 tersebut ditampilkan sinyal pada komponen horisontal East-West (HNE), horisontal North-South (HNN) dan komponen up-down vertikal Z (HNZ). Data gempa dapat diunduh langsung dari logger di stasiun pengukuran dan dapat juga diunduh di kantor BMKG selama data itu masih tersimpan dalam media penyimpanan. Dalam penelitian ini data diambil/didownload dari data yang tersimpan di kantor BMKG (stasiun geofisika Yogyakarta).

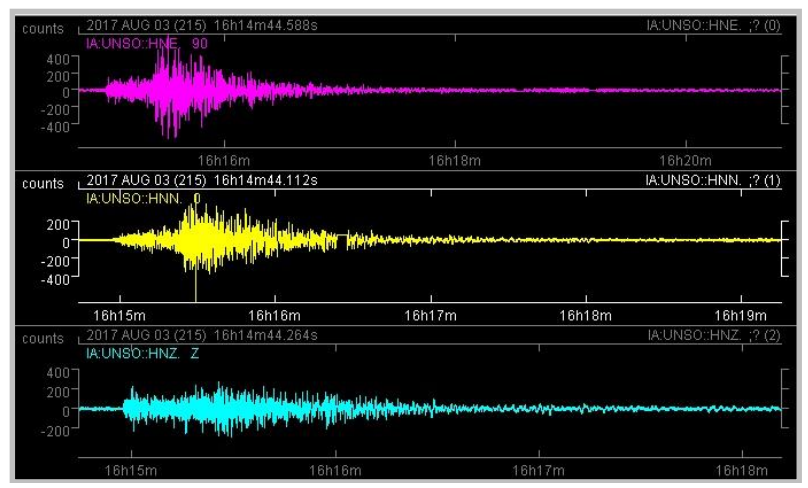

Gambar 1. (color online) Tampilan seismogram gempa komponen E-W, N-S dan Z

Data rekaman (sinyal) yang terukur oleh sensor merupakan data yang akan dihitung menjadi nilai PGA dengan bantuan software DadiSP ${ }^{[9]}$. Rekaman sinyal yang terekam oleh sensor yang telah diunduh format data dirubah kedalam format SAC atau format yang lain yang lebih fleksibel dan sesuai dengan software pengolah datanya. Kita dapat mengunduh data dengan durasi tertentu sesuai dengan event gempabumi yang kita proses. Data rekaman atau sinyal yang kita peroleh dapat kita gunakan sesuai kebutuhan misalnya mengetahui nilai PGA atau melihat spektrumnya untuk mengetahui kandungan frekuensi dominannya. Sinyal yang diperoleh dari sensor masih dalam bentuk count belum bersatuan, maka sinyal akan dirubah menjadi bersatuan percepatan tanah maksimum 
dalam gal seperti tersebut diatas. Satuan dalam bentuk count pada sumbu-y dirubah menjadi gal, sekaligus mencari nilai percepatan tanah maksimum. Untuk merubah sinyal dan mendapatkan nilai percepatan tanah maksimum perlu nilai konversi faktor yang pada masing-masing alat berbeda. Untuk di site sensor UNSO konversi faktornya sesuai dengan type sensor yang terpasang (TSA 100) yaitu seperti ditunjukan tabel 1.

Tabel 1. Faktor Konversi TS 100 site sensor UNSO

\begin{tabular}{|c|c|c|c|c|c|c|}
\hline \multirow[t]{2}{*}{ Posisi } & \multirow[t]{2}{*}{ Type sensor } & \multirow[t]{2}{*}{ Digitizer } & \multirow[t]{2}{*}{ Sampling } & \multicolumn{3}{|c|}{ Faktor konversi } \\
\hline & & & & Komponen $\mathbf{N}$ & Komponen E & Komponen Z \\
\hline$-7,56 \mathrm{LS} 110,85 \mathrm{BT}$ & TSA-100S & TAURUS & 100 & $4,70 \mathrm{E}-07$ & $4,70 \mathrm{E}-07$ & $4,70 \mathrm{E}-07$ \\
\hline
\end{tabular}

Sinyal rekaman masing-masing yang masih bentuk count dikalikan faktor konversi maka sinyal sudah dalam satuan g persamaan 6. Untuk bersatuan gal maka harus dikalikan nilai gravitasi (980) seperti ditunjukan persamaan 7, maka sinyal akan bersatuan gal. Nilai puncak untuk masing-masing komponen merupakan nilai percepatan tanah maksimum.

Nilai PGA ini selanjutnya dapat dikonversikan ke besaran Intensitas atau yang umum dikenal dengan sebutan MMI (Modified Mercalli Intensity). Nilai PGA dapat diambil dari resultan komponen horizontal dan vertical. Maupun dapat juga diketahui untuk nilai PGA pada masing-masing komponen. Nilai PGA yang diperoleh kemudian dikonversikan untuk memperoleh nilai intensitas gempa dalam bentuk MMI ${ }^{[10]}$. Konversi ke dalam nilai intensitas dengan menggunakan table 2 .

Tabel 2. Konversi nilai percepatan tanah ke Intensitas

\begin{tabular}{cccccccccc}
\hline Intensitas & I & II-III & IV & V & VI & VII & VIII & IX & X+ \\
\hline $\begin{array}{c}\text { Peak } \\
\begin{array}{c}\text { cceleration } \\
(\% \mathrm{~g})\end{array}\end{array}$ & $<0,17$ & $0,17-1,4$ & $1,4-3,9$ & $3,9-9,2$ & $9,2-18$ & $18-34$ & $34-65$ & $65-124$ & $>124$ \\
\hline
\end{tabular}

\section{Peralatan}

Peralatan accelerograph yang dipasang di sensor site UNSO type TSA 100 merupakan produk dari Metrozet USA, model dan tampilan sensor type TSA 100 ditunjukan gambar 2. Spesifikasi accelerograph TSA-100 sebagai berikut:

Strong Motion Sensor : +/- 4 g Range

Wide Bandwidth $\quad$ : DC to $>225 \mathrm{~Hz}$

Low Noise $\quad: 2,2 \times 10-8 \mathrm{~g} / \mathrm{rtHz}$ at $1 \mathrm{~Hz}$

Low Thermal Drift : 60 micro-g/oC

High Dynamic Range : $162 \mathrm{~dB}$ at $1 \mathrm{~Hz} 137 \mathrm{~dB}, 0.1 \mathrm{~Hz}$ to $100 \mathrm{~Hz}$, Integrated

High Accuracy $\quad: 0.015 \%$ Total Non-Linearity

Ultra-Low Hysteresis : 0.005\% 

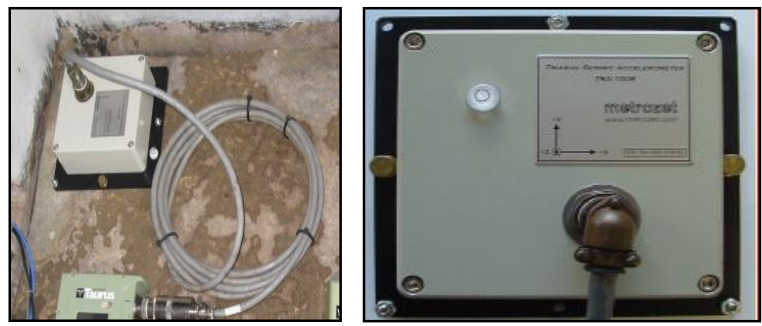

Gambar 2. (color online) Sensor TSA 100 Metrozet

\section{HASIL DAN PEMBAHASAN}

Berdasar pada hasil perhitungan nilai percepatan tanah pada masing masing komponen accelerogram di stasiun pengukuran UNSO dari gempa yang terjadi pada tanggal 03Agustus 2017, komponen N-S mempunyai nilai PGA 0,307, komponen E-W mempunyai nilai PGA 0.302 komponen U-D mempunyai nilai PGA 0.133.

Tabel 3. Nilai PGA setiap komponen accelorgraph UNSO

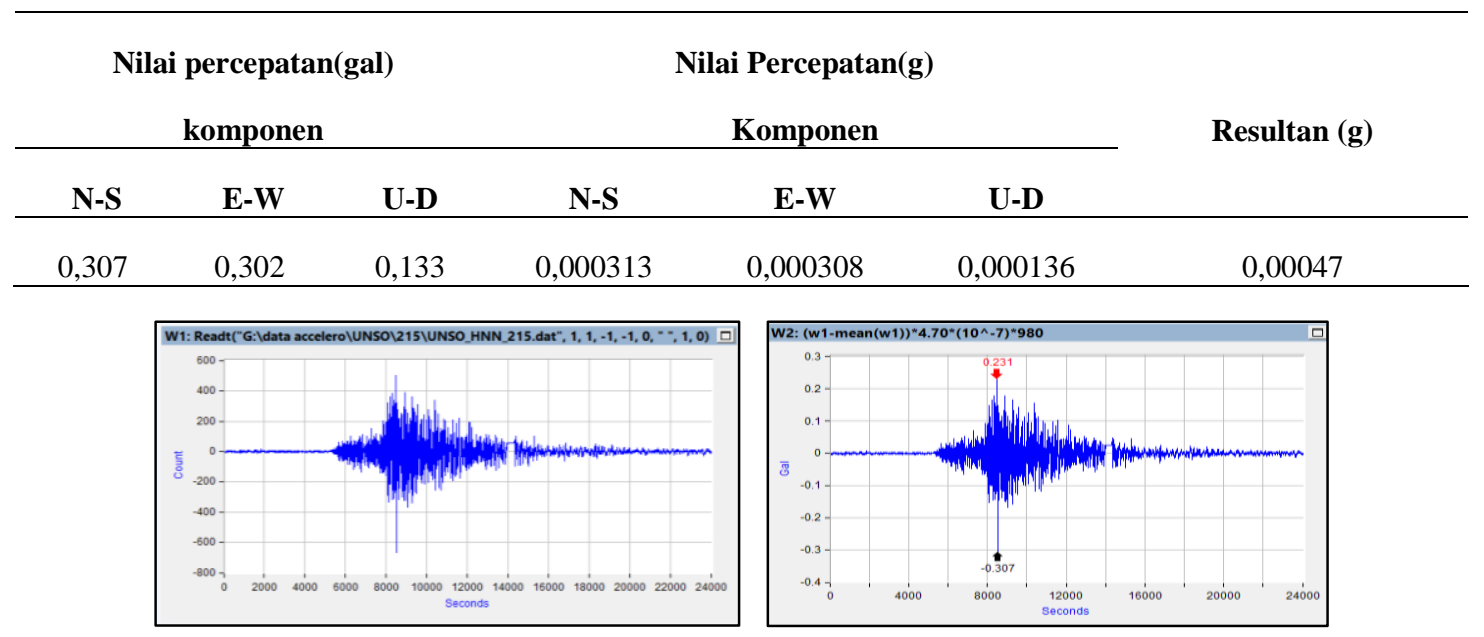

a.
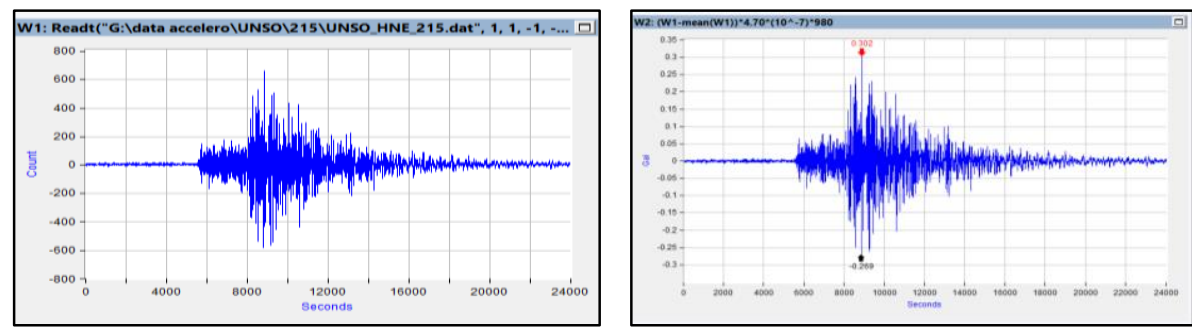

b.
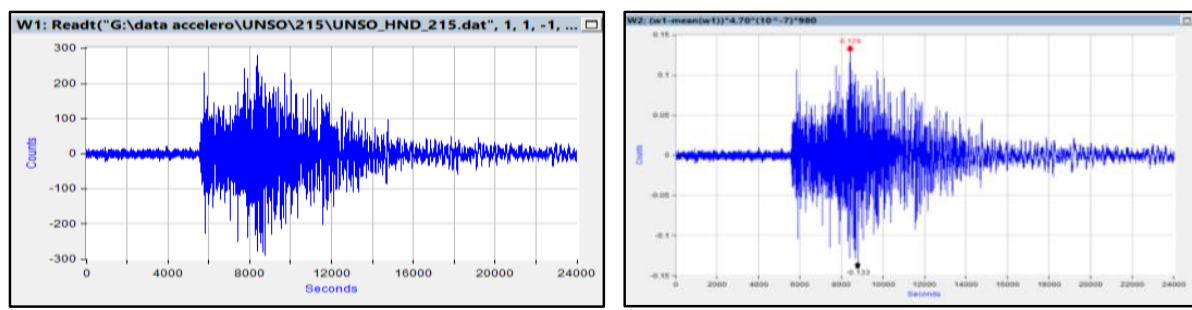

c.

Gambar 3. (color online) Tampilan sinyal dan nilai maksimum a. Komponen N-S, b. Komponen E-W c. Komponen UpDown 
Nilai ini merupakan nilai maskimum yang diperoleh masing-masing komponen sensor seperti ditunjukan oleh Tabel 3 dan Gambar 3. Pada umumnya yang digunakan adalah komponen horisontal, sehingga dari nilai-nilai yang ada PGA akibat gempabumi bernilai 0,307 gal. Nilai PGA terukur dirubah menjadi bentuk nilai intensitas gempabumi dengan menggunakan konversi shake map USGS dalam (\%g) seperti ditunjukan tabel 4. Gempabumi yang terjadi terekam di stasiun pengukuran UNSO mempunyai nilai maksimum 3,13 $10^{-6}(\% \mathrm{~g})$ sehingga nilai intensitasnya adalah I MMI. Gempabumi dengan nilai intensitas I berdasarkan penjelasan pada skala MMI mempunyai keterangan tidak dirasakan kecuali oleh beberapa orang dalam keadaan sangat tenang. Tabel skala intensitas (MMI) ditunjukan oleh table 4 (dari Bolt, Bruce A. Abridge Modified Mercalli Intensity Scale, 1993, dalam Sukanta, I. N., dkk) ${ }^{[8]}$. Nilai percepatan tanah ini sangat tergantung kondisi site, jarak dari sumber dan besarnya magnitudo gempabumi. Semakin jauh dari sumber gempa maka nilai PGA nya semakin rendah. Namun demikian kondisi geologi setempat juga mempengaruhi nilai PGA. Daerah yang dekat dengan sumber gempabumi dapat bernilai lebih kecil sedangkan daerah yang jauh dapat bernilai lebih besar.

Tabel 4. Nilai Konversi dan Intensitas MMI

\begin{tabular}{|c|c|c|c|c|c|c|}
\hline \multirow{6}{*}{$\begin{array}{l}\text { Average } \\
\text { Peack } \\
\text { Velocity } \\
(\mathrm{cm} / \mathrm{s})\end{array}$} & & \multirow{2}{*}{$\begin{array}{l}\text { Nilai Intensitas dan Penjelasanya } \\
\begin{array}{l}\text { Tidak dirasakan kecuali oleh beberapa } \\
\text { orang dalam keadaan sangat tenang }\end{array} \\
\end{array}$} & \multirow{2}{*}{$\begin{array}{l}\text { Average Peak } \\
\text { Acceleration } \\
\text { (gals) }\end{array}$} & \multirow{2}{*}{$\begin{array}{c}\text { Average } \\
\text { Peak } \\
\text { Acceleratio } \\
\mathrm{n}(\mathrm{g} \text { atau } \\
\text { gravity }= \\
\left.9,80 \mathrm{~m} / \mathrm{s}^{2}\right)\end{array}$} & \multicolumn{2}{|c|}{ ShakeMap-USGS (\%g) } \\
\hline & I & & & & $<0,17 \% \mathrm{~g}$ & $0,0017 \mathrm{~g}$ \\
\hline & II & $\begin{array}{l}\text { Dirasakan oleh beberapa orang yang diam, } \\
\text { terutama di lantai-lantai atas bangunan. } \\
\text { Benda-benda ringan yang digantung } \\
\text { bergoyang. }\end{array}$ & & & $0,17-1,4 \% \mathrm{~g}$ & $0,0017-1,014 \mathrm{~g}$ \\
\hline & III & $\begin{array}{l}\text { Dengan jelas terasa didalam ruangan, } \\
\text { terutama dilantai-lantai atas } \\
\text { bangunan/gedung, namun banyak yang } \\
\text { tidak menyadari terjadi gempa. Kendaraan } \\
\text { yang sedang berdiri sedikit bergoyang. } \\
\text { Getaranya seperti truk yang melintas. } \\
\begin{array}{l}\text { Durasi (lamanya) getaran dapat } \\
\text { diperkirakan. }\end{array}\end{array}$ & & & & \\
\hline & IV & $\begin{array}{l}\text { Saat siang hari didalam ruangan, terutama } \\
\text { dirasakan oleh banyak orang, sedang } \\
\text { diluar ruangan hanya sedikit orang yang } \\
\text { merasakan. Pada malam hari beberapa } \\
\text { orang terbangun. Piring, jendela dan pintu } \\
\text { bergetar atau bergoyang-goyang. Dinding } \\
\text { berderik. Terasa seperti truk yang } \\
\text { menabrak bangunan. Motor dan mobil } \\
\text { yang sedang diam dengan jelas terlihat } \\
\text { bergoyang. }\end{array}$ & $14,7-19,6 \mathrm{gal}$ & $\begin{array}{l}0,015 \mathrm{~g}- \\
0,02 \mathrm{~g}\end{array}$ & $1,4-3,9 \% \mathrm{~g}$ & $0,014-0,039 \mathrm{~g}$ \\
\hline & $\mathrm{V}$ & $\begin{array}{l}\text { Dirasakan oleh hampir semua orang, } \\
\text { banyak yang terbangun. Piring, jendela } \\
\text { dan sebagainya pecah, plester bangunan } \\
\text { retak-retak, di bagian kecil bangunan, } \\
\text { benda-benda yang tidak stabil terbalik. } \\
\text { Pohon-pohon, tiang dan benda-benda } \\
\text { tinggi lainya terlihat bergerak-gerak. Jam } \\
\text { bandul berhenti. }\end{array}$ & $29,4-39,2 \mathrm{gal}$ & $0,03-0,04 \mathrm{~g}$ & $3,9-9,2 \% \mathrm{~g}$ & $0,039-0,092 \mathrm{~g}$ \\
\hline
\end{tabular}


Lanjutan Tabel 4

\begin{tabular}{|c|c|c|c|c|c|c|}
\hline \multirow{2}{*}{\multicolumn{2}{|c|}{$\begin{array}{l}\text { Average } \\
\text { Peack } \\
\text { Velocity } \\
(\mathrm{cm} / \mathrm{s})\end{array}$}} & \multirow{2}{*}{$\begin{array}{l}\text { Nilai Intensitas dan Penjelasanya } \\
\text { Dirasakan oleh semua orang, banyak yang } \\
\text { ketakutan dan berlarian keluar. Beberapa } \\
\text { furniture berat bergeser, plester-plester } \\
\text { dinding berjatuhan dan cerobong asap } \\
\text { mengalami kerusakan ringan. }\end{array}$} & \multirow{2}{*}{$\begin{array}{l}\begin{array}{c}\text { Average Peak } \\
\text { Acceleration } \\
\text { (gals) }\end{array} \\
58,8-68,8 \text { gal }\end{array}$} & \multirow{2}{*}{$\begin{array}{l}\text { Average } \\
\text { Peak } \\
\text { Acceleration } \\
\text { (g atau } \\
\text { gravity }= \\
\left.9,80 \mathrm{~m} / \mathrm{s}^{2}\right) \\
0,06-0,07 \mathrm{~g}\end{array}$} & \multicolumn{2}{|c|}{ ShakeMap-USGS (\%g) } \\
\hline & & & & & $9,2-18 \% \mathrm{~g}$ & $0,092-0,18 \mathrm{~g}$ \\
\hline & VII & $\begin{array}{l}\text { Semua orang berlarian keluar, kerusakan } \\
\text { ringan pada bangunan dengan struktur } \\
\text { standar, namun kerusakan sangat besar } \\
\text { pada bangunan dengan struktur jelek. } \\
\text { Beberapa cerobong asap retak-retak. } \\
\text { Gempa dirasakan juga oleh orang yang } \\
\text { naik kendaraan. }\end{array}$ & 98-147 gal & $0,10-0,15 \mathrm{~g}$ & $18-34 \% \mathrm{~g}$ & $0,18-0,34 \mathrm{~g}$ \\
\hline & VIII & $\begin{array}{l}\text { Kerusakan ringan pada bangunan yang } \\
\text { dirancang dengan struktur khusus, } \\
\text { kerusakan besar pada bangunan struktur } \\
\text { standar dan meruntuhkan bangunan } \\
\text { dengan struktur jelek. Dinding-dinding } \\
\text { dapat terlepas dari kerangka rumah. } \\
\text { Cerobong asap pabrik-pabrik dan } \\
\text { monumen-monumen roboh. Furniture } \\
\text { (meja kursi) berat terlempar. Pasir dan } \\
\text { lumpur (dalam jumlah kecil) tersembur } \\
\text { keluar. }\end{array}$ & 245-294 gal & $0,25-0,30 \mathrm{~g}$ & $34-65 \% \mathrm{~g}$ & $0,34-0,65 \mathrm{~g}$ \\
\hline & IX & $\begin{array}{l}\text { Kerusakan bangunan terjadi pada } \\
\text { bangunan yang sangat kokoh. Rangka- } \\
\text { rangka bangunan biasa terlepas dari } \\
\text { pondasinya. Kerusakan besar pada } \\
\text { bangunan kuat dengan sebagian besar } \\
\text { bangunan roboh. Pondasi bangunan } \\
\text { bergeser. Tanah retak-retak, pipa bawah } \\
\text { tanah pecah. }\end{array}$ & 490-539 gal & $0,50-0,55 \mathrm{~g}$ & $65-124 \% \mathrm{~g}$ & $0,65-1,24 \mathrm{~g}$ \\
\hline & $\mathrm{X}$ & $\begin{array}{l}\text { Bangunan dari kayu rusak, sebagian besar } \\
\text { bangunan kayu dan bangunan } \\
\text { berkerangka fondasi rusak. Retak-retak } \\
\text { besar ditanah. Rel melengkung. Longsor } \\
\text { disekitar pinggiran sungai serta lereng } \\
\text { curam. Pasir dan lumpur bergeser. Terjadi } \\
\text { bah di pinggir sungai. }\end{array}$ & $>580$ gal & $>0,6 \mathrm{~g}$ & $>124 \% \mathrm{~g}$ & $>1,24 \mathrm{~g}$ \\
\hline & XI & $\begin{array}{l}\text { Hanya sedikit bangunan yang masih } \\
\text { berdiri. Jembatan-jembatan rusak. Retak- } \\
\text { retak lebar pada tanah. Pipa bawah tanah } \\
\text { rusak total. Terjadi liquifaksi pada tanah } \\
\text { yang lunak. Rel kereta melengkung } \\
\text { sangat parah. }\end{array}$ & & & & \\
\hline & XII & $\begin{array}{l}\text { Kerusakan total. Gelombang tampak di } \\
\text { permukaan tanah. Pemandangan menjadi } \\
\text { gelap. Benda-benda terlempar ke udara. }\end{array}$ & & & & \\
\hline
\end{tabular}

Hal ini karena pengaruh dari keadaan geologi setempat yang dapat mengakibatkan amplifikasi maupun diamplifikasi getaran gempa. Penempatan sensor yang tepat akan memberikan nilai akurat sehingga perlu diperhatikan penempatan sensor yang benar. Sensor sebaiknya ditempatkan pada tempat dengan kondisi geologi yang keras sehingga 
rekaman yang dihasilkan merupakan rekaman yang bagus terhindar dari ganguan (noise). Rekaman getaran tanah sangat berguna untuk dalam pembuatan building code untuk keamanan bangunan.

\section{KESIMPULAN}

Stasiun pengukuran UNSO dapat memberikan data percepatan tanah Maksimum (PGA) dari getaran gempabumi yang terekam. Nilai Percepatan Tanah Maksimum di site sensor UNSO masing-masing komponen akibat gempa 03 Agustus 2017 bernilai 0,307 gal (N-S), 0,302 gal (E-W) dan 0,133 gal (E-W). Intensitas di stasiun pengukuran UNSO di Universitas Sebelas Maret Surakarta dan sekitarnya bernilai I MMI.

\section{UCAPAN TERIMA KASIH}

Penulis mengucapkan terimakasih kepada Kepala Stasiun Geofisika Yogyakarta dan Kepala Seksi Observasi Pusat Gempa Regional VII atas ijin yang diberikan untuk dapat mengakses dan mengolah data yang terdapat di Pusat Gempa Regional VII.

\section{DAFTAR PUSTAKA}

1. Verstapen, H.TH. 2010. Indonesian Landform and Plate tectovics. Jurnal Geologi Indonesia, 5 (3), 197-207.

2. Hamilton, W. 1993. Tectonics of the Indonesian Region. Geol. Soc. Malaysia, 6, 3-10.

3. Gunawan, I. \& Subardjo. 2004. Pengetahuan Seismologi, Badan Meteorologi dan Geofisika. Jakarta.

4. Sabtaji, A., dkk. 2006. Estimasi Perhitungan Percepatan Tanah Gempabumi Utama Nabire dan Jogjakarta Menggunakan Data Accelerograph Gempabumi Susulan. Jurnal Meteorologi dan Geofisika, 7 (3).

5. Prayitno, B. \& Ponimin S. 2006. Accelerograph, Materi Workshop peralatan Geofisika, Softcopy Diktat Modul pelatihan (training) peralatan geofisika 5-9 Juni 2006

6. Dadafshar, M., 2014. Accelerometer and Gyroscopes Sensors: Operation, Sensing, and Applications, Aplication Note 5830

7. Boore, D. \& Bommer M. J. J. 2004. Processing of strong-motion accelerograms: needs,options and consequences. Soil Dynamics and Earthquake Engineering, 25 (2), 93-115.

8. Sukanta I. N., dkk, 2010. Accelerograph BMKG dalam Penentuan Peta Intensitas Gempa Kuat. Puslibang BMKG https://www.scribd.com/document/84227253/139

9. Getting Start with DadiSP. http://www.dadisp.com/files/getstart.pdf.

10. William, H. K. L., Kanamori, H., Jennings P. C., \& Kisslinger, C. 2003. International Handbook of Earthquake and Engineering Seismology. Elsevier. 